\title{
ROLE AND STATUS OF COMMUNICATION EXPERTS IN THE PO- LICE
}

\section{ULOGA I STATUS KOMUNIKACIJSKIH STRUČNJAKA U POLICIJI}

\author{
Anita Kovačič Čelofiga ${ }^{1}$, Mario Plenkovićc \\ Alma Mater Europaea, Maribor, Slovenia; Faculty of Graphic Arts, University of Zagreb, Zagreb, Croatia E Alma Mater \\ Europaea, Maribor, Slovenia ${ }^{2}$ \\ Alma Mater Europaea, Maribor, Slovenija1; Grafički fakultet, Sveučilište u Zagrebu, Zagreb, Hrvatska E Alma Mater \\ Europaea, Maribor, Slovenija
}

\section{Abstract}

Police work is constantly at the forefront of media coverage and public interest - there are only few State Institutions that are subject to as much media and public attention as the police. Public relations, therefore, shape its image importantly, and, at the same time, differ from the public relations in public administration and the private sector due to its specific nature. The article discusses the work of Slovenian police communication experts, their position and status, as well as their position in comparison with their foreign colleagues, and communicators in the public and private sectors. We examined the content and systemic limitations of Slovenian police communication experts and found that they are faced with lack of media experience, appropriate education and knowledge of contemporary skills. Key reasons for this situation are several: An inadequate staffing policy, organisation, implementation of public relations and lack of employee training. These limitations are also the main factors why police communication experts devote most of their time to the technical level of public relations, even if, for higher quality and modern public relations, they should act more often in a strategic role.

\section{Introduction}

Police work is constantly at the forefront of media coverage and publicity - only a few State Institutions are the subject of as much interest from the media and various public as the police.
Sažetak

Rad policije je stalno u prvom planu medijskih izvještavanja i javnog interesa - malo državnih institucija koje podliježu tolikoj medijskoj i javnoj pozornosti kao policija. Odnosi s javnostima, dakle, značajno oblikuju njezin imidž i istovremeno se razlikuju od odnosa $\mathrm{s}$ javnostima $\mathrm{u}$ javnoj $\mathrm{u}$ pravi i privatnom sektoru zbog svoje specifičnosti. U članku se govori o radu slovenskih stručnjaka za komunikaciju u policiji, njihovom položaju i statusu, te njihovom položaju u usporedbi sa stranim kolegama i komunikatorima u javnom i privatnom sektoru. Ispitali smo sadržaj i sistemska ograničenja slovenskih stručnjaka za komunikaciju u policiji i otkrili da su suočeni s nedostatkom medijskog iskustva, odgovarajuće edukacije i poznavanja suvremenih vještina. Ključni su razlozi za takvu situaciju: neadekvatna kadrovska politika, organizacija, provedba odnosa s javnostima i nedostatak obuke zaposlenika. Ta su ograničenja glavni čimbenici zbog kojih stručnjaci za policijsku komunikaciju većinu svog vremena posvećuju tehničkoj razini odnosa s javnostima, čak i ako bi za kvalitetniji i moderniji odnos s javnostima češće trebali igrati stratešku ulogu.

By enforcing the public interest, the police, on the one hand, work for the public, at the same time, their work is public, because it is happening in full view of the public /1/. By informing 
the public of their own activities and efforts systematically, the police build confidence, which is a prerequisite for public participation /2/. Because of reliance on public support, organisations such as the police must be very cooperative and open $/ 3 /$. Without citizen participation, it is less successful in solving problems in the fields of Crime Prevention and Suppression, Maintaining Public Order and managing other security tasks $/ 4 /$. Those who do not trust the police are hesitating when turning to police officers for help, reluctant to report a crime or provide useful information /5/, /6/. Public distrust also threatens its legitimacy $/ 7 /$, especially when the integrity and reputation of the police organisation are under scrutiny /8/. The perception of police legitimacy also depends on its presentation in the media $/ \mathbf{9} /, / \mathbf{1 0} /, / \mathbf{1 1} /$, as mass media reporting has a significant impact on shaping people's attitudes toward the police $/ \mathbf{1 2} /, / \mathbf{1 3} /$, $/ \mathbf{1 4} /, / \mathbf{1 5} /, / \mathbf{1 6} /, / \mathbf{1 7} /$. Although general trust in the mass media is declining $/ \mathbf{1 8} /$, they are still one of the most influential and important sources of information received about the world.

Journalists pay close attention to the work of public employees and often report on their work. Public employees are more exposed on formal constraints, subjected to various external informal influences and high expectations of the public for justice and constant control over their work /19/. Baker /20/ considers that most journalists have a negative attitude towards the government and its public relations. Especially because of the nature of their work, police officers are more likely to find themselves exposed in media among the public /10/, /21/, /22/. Due to the power and authority that goes beyond other public and private organisations, they are expected to have a higher level of public accountability /23/. Although the media often report on the deviant behaviour of police officers, they are not as reluctant to the police as their employees often feel $/ \mathbf{1 0} /$, as the overall media image of police work is positive /24/. Kesetovic is similar in saying that the media support the police and their role in society, but their relations are often fraught with many problems because of different, sometimes conflicting views, values, norms, logic, interests, rules and regulations; the relationship between journalists and police officers is subject to constant conflict, and many misunderstandings can also lead to serious tensions and breaking contacts between the police organisation and the media /25/. Establishing good relations with the media is especially important for a police organisation that seeks a higher level of trust and support /10/. Public support can also be influenced by organised, targeted and managed implementation of public relations $\mathbf{2 6 /} /$. In the ordinary and everyday interrelationships, both the police and the media benefit. Journalists rely on the police to provide them with information about criminal events of interest to the public, and the police need the media to maintain or improve their reputation, to report major crime and to search for wanted persons and witnesses /27/. Journalists rely on information from police public relations experts, as their straightforward and most cost-effective option /3/. At the same time, contributions based on police resources are considered more credible. Because they do not want to jeopardise a relationship that enables them to produce news quickly and easily, journalists are usually not critical of the information they receive from the police $/ \mathbf{2 8} /$.

Police officers are the most common source of information in the media, with journalists receiving more than $70 \%$ of information about criminal events from police institutions $/ \mathbf{2} /, / 29 / / 30 /$, and police information is often presented, making the news itself /32/. Media space is filled quickly, with minimal cost, stories are well read and their authors are exposed /28/. Such information dependence of the media empowers police sources to disseminate information in the way that best suits and benefits them $/ 29 /$. With their exclusive access to information about crime, they can thus influence what news, when and how it will be presented to the public, and use crime to self-promote or divert attention /28/. Media reporting plays an important role in the development of people's attitudes towards the police organisation /17/. Although, increasingly, younger generations are turning to the web for information, traditional media remain the most important sources of information about crime and public safety and policing among the general public $/ 22 /, / 31 /, / 33 /, / 34 /$. In addition to the other sources of information on 
which people create their social realities ${ }^{4}$, the media are also crucial in shaping the public's perception of particular social phenomena. Most people do not have direct personal experience with the police or crime, and their main sources of opinion are only indirect ${ }^{5} / 35 /, / 36 /$. Because people are interested in news about crime, violence and police activities in the safety of their living rooms $/ \mathbf{1 0} /, / \mathbf{2 1} /, / \mathbf{3 7} /$, there is an enormous amount of media space dedicated to crime $/ \mathbf{1 0} /, / \mathbf{3 0} /, / \mathbf{3 2} /$. The interest in "right and wrong", "good and evil" is inherent in humans /38/, Beck /39/ adds that people are fascinated by the dark side of human nature. We live in a society of insecurity and risk, in which people respond with enthusiasm to every sign of danger and threat $/ 39 /, / 41 /$. In such an environment, perceptions of crime and insecurity are becoming more pronounced, and increasingly influencing society as tools for managing it /42/. Media reporting on crime and violence affects the perception of crime in society and the fear of crime $/ \mathbf{1 2} /, / 21 /, / 31 /, / 37 /, / 38 /$, A single violent event, widely reported by the media, can have an effect on public insecurity /43/. The social construction of reality is actually the media construction of reality /44/. As media coverage of crime is distorted in both qualitative and quantitative terms, it is flawed and can be false /45/. News of crime are most popular media content $/ 31 /, / 46 /, / 47 /$. The share of crime news has increased, especially in recent decades $/ \mathbf{2 2} /$, $/ 48 /$. About $11 \%$ of all news is crime related, which places them fourth in frequency /29/. In an analysis of Slovenian daily television news programmes, Prpič /49/ concludes that contributions on wars, conflicts, crime and security are the second most common, with the most contributions on violent crime and property crimes. In the analysis of crime reporting, in the most widely read Slovenian newspaper, Slovenske novice, one-third of the news refers to violence, to which the majority of the space is addressed /50/. In particular, deviant behavio-

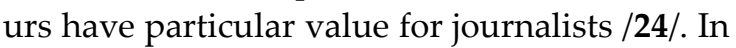

\footnotetext{
${ }^{4}$ People's behaviour about social events is based on four different sources of information, on the basis of which people create their social realities; these are personal experiences, significant others (eg. peers, family and friends), other
}

order to attract people's attention, the media select only the most spectacular part of the crime, and present it in a populist and sensationalist way $/ \mathbf{1 2} /, / 47 /$. Crime reporting and policing have become the primary means of communication between police institutions and the outside public $/ \mathbf{3 0} /$, thus contributing to police communication professionals contributing to media reporting in a sensationalist way, to distorting social realities and creating false feelings about the incidence of crime and other major critical events.

\section{Police communicators in relation to the public sector}

Not only police, but also wider, government public relations, play an important role, as they take place at all levels of life that concern us. Like the public, the private sector is subject to similar professional principles and basic characteristics, which differ in many respects and are implemented differently /19/, /51/. Due to the many stakeholders, different interests and political priorities, communication in State administration is more important than in business organisations $/ 19 /, / 20 /$. Employees of the executive, legislative and judicial branches of government, government and government agencies, various stakeholders, political party representatives, State and local officials, businessmen, media representatives and the general public monitor public relations programmes, and often have budgetary power or public opinion over them $/ \mathbf{2 0}$. The main difference between the sectors is also the provision of $\mathrm{pu}$ blic goods in the same way and under the same conditions for all citizens, with the provision of public goods as a public interest, ie. health, pension and social care, social services, police, firefighters, employment services, public transport and telecommunications, education, waste collection... /19/. Communication in the public sector is diverse in content and interspersed with many complex programmes, policies and projects $/ 55 /$. The diversity of goals, activities and

social groups and institutions (Schools, Associations, Churches and State Institutions) and the mass media /12/.

${ }^{5}$ Only about one-fifth of citizens have direct experience with police officers $/ 22 /, / 40 /$. 
skills of communicators are also greater /52/. For political, bureaucratic and financial reasons, the public relations process itself is also limited in its public relations process ${ }^{6}$, in which research and evaluation are often omitted ${ }^{7} / 52 /$.

The private and public sectors are also segregated by conditions and circumstances that affect the work of public relations experts. Public relations management is influenced by specific cultural factors and formal or informal forms of political system $/ \mathbf{2 0 / .}$. When public relations in the private sector are more exposed to the market, the public is subject to formal coercion - various external informal influences and high public expectations for the fairness of their activities and constant control over them /19/, which is especially evident in the police public relations. Also, the tasks and functions of police public relations cannot be compared fully to the rest of the government public relations. Due to the content, which differs from other police tasks, the scope of work, the required character of the employee and specific skills /53/, we treat police public relations as a separate police function. What they have in common with the public sector are general legal, administrative and financial regulations and restrictions that determine State public relations /54/. Police communication professionals must also strive for public and transparent work, and prompt and open communication to the public through the direct flow of information, and must respect the professional and ethical principles applicable to the performance of public relations tasks. However, due to their distinctive status, work and roles in society, police relations are identified by specific limitations and specificities. According to Kešetović, the distinction is due primarily to the fact that, without the support and participation of the public, the police cannot achieve their primary goal, ie. ensuring the safety of citizens. In order to overcome apathy, indifference and hostile publicity, employees need to recognise that good public relations is something that enables them to do their jobs better and more securely $/ 53 /$.

\footnotetext{
${ }^{6}$ The usual steps of the communication process are research, planning, implementation and evaluation /51/.
}

Police communication professionals are required to have a broad and specific professional competence in both public relations and police work, as well as a high level of professionalism and ethics. They are not only subject to the rules and restrictions of civil servants, as police officers must comply with stricter rules on ethical conduct and integrity. Unlike their counterparts in the public sector, they still act as official speakers, and are more often under public scrutiny due to their media exposure. Often, the information at their disposal is extremely sensitive and disclosing it could have irreparable consequences, damage the reputation of the police and jeopardise police and judicial proceedings, thereby undermining the foundations of the legitimacy of the justice system. As a result, they may be more likely to be subject to internal security procedures and complaints by those involved, often better known to the public involved in various police procedures. Compared to colleagues in government, the work of a police public relations representative can be mentally and physically strenuous, as it involves reporting from the scene of a crime or serious accident, responding on weekends and holidays, at night, or at times when they need to report on police irregularities. Police communication professionals are responsible for all communication with the media, and are their primary source of information on police activities $/ \mathbf{1 0} /$. The great interest of the public and the media in information on police activities, as well as the journalists' extreme reliance on information from police institutions, places strong pressure on police organisations and their selection of appropriate staff to communicate with journalists /2/. From formerly ancillary, supportive functions, public relations today are an integral part of police work and organisational structure. Police organisations employ full-time experts in the work of public relations representatives, who either act as civilians or have police powers. Communication professionals are better prepared for a variety of journalistic requirements, as they have staff trained to decide what information is relevant to the public /30/. Recognising that, to some extent, by engaging

\footnotetext{
${ }^{7}$ Communicators do not engage in research because of the need for swift action, and performance evaluation is often limited to the question of policy points gained or public opinion /51/.
} 
with the journalist, they can influence their image in the media $/ \mathbf{9} /, / \mathbf{1 0} /, / \mathbf{2 7} /, / 55 /$. Police organisations invest considerable resources in public relations, and use a variety of strategies to help the media produce news and influence their media presentation $/ \mathbf{2 8} /, \mathbf{3 0} /$. They are aware that, with the help of police communication experts, they can maintain better relationships with journalists, thereby ensuring publicity and maintaining the institution's reputation $/ \mathbf{1 0} /, / \mathbf{2 8} /, / \mathbf{3 0} /$. The effectiveness of State relations with the public depends in particular on the organisation and definition of the relations' responsibilities and responsibilities of public relations services and public sector communicators $/ \mathbf{1 9} /$. In the Slovene State administration, each Ministry has its own Public Relations Department, which is usually the case with the constituent bodies. The Slovenian Police, as an independent organisational structure within the police organisation at the State level, has a Public Relations Division, an umbrella expert service within the Directorate General of Police, where it organises, plans and manages public relations. At the regional level, each police department has its own public relations representative employed by the police department. Employees in the Public Relations Division are accountable to their immediate superior and the Director General of the Police, and are professionally independent in communication, but must take into account the opinions and decisions of the departments responsible for particular areas of police work ${ }^{8}$. Police spokespersons at the regional level communicate on behalf of the Police Directorate, and are restricted to the area and the Police Directorate level, and are its official speakers. They can inform the public directly, but they must consult ${ }^{9}$ a professional service, a director of the administration or the $\mathrm{Pu}-$ blic Relations Division /56/ about important, more significant and sensitive cases. The police inform the public about their own work under the Organisation and Work in the Police Act (Article 34) if it does not prejudice the performance of police tasks or the legitimate benefits of others $/ 57 /$. By providing information, it guarantees publicity and openness of work, as it is

\footnotetext{
${ }^{8}$ In particular, they make general statements on police-related topics on their own, and may also request a specialist service for information $\mathbf{~} \mathbf{5 6} /$
}

committed to providing the public with the best possible information /56/. Police communicators must comply with constitutional provisions (notably the principle of alleged innocence and separation of powers), as well as laws (Personal Data Protection Act, Criminal Code, Criminal Procedure Code, Media Act, Access to Public Information Act), and guidelines and rules such as Public Relations Policing Policies, Public Emergency Policing Crisis and Conflict Guidelines, and Police Information and Reporting Policies /56/. The public expects a lot from the police, but, at the same time, does not understand the limitations and obstacles that the police face in their work in various operational areas and situations. Police operate in a world dominated by emergencies and crises; on a daily basis, police officers deal with individuals involved in crises of varying magnitude /23/. Pressures from the media and the public are particularly strong when a high-profile case arises, or when it comes to police misconduct. The tone of reporting and the accuracy of information, which depend on the availability and responsiveness of the media relations representative are, therefore, of particular importance /58/. Only competent staff with appropriate knowledge, skills and personal attributes can occupy the position of police communication expert. The profession of police communications expert requires a well-developed sense of managing and presenting crime information for the benefit of the institution, which requires an understanding of the needs of journalists and media formats, as well as an appropriate attitude and level of communication with journalists /22/. In order to plan, organise and carry out communication activities in a quality manner, the communicator must be well informed on all relevant events and police activities /56/. Being recognised as an expert and trusted by employees, especially with management, makes it easier to obtain useful information, which is especially important when working with operational employees in the event of major police events. Primary responsibilities of police communication professionals include disseminating information about daily police activities

\footnotetext{
${ }^{9}$ Coordination is also necessary in cases where events exceed the level of police administration, or communication is linked to the work strategy of the police, professional instructions, individual provisions of laws and the work of other bodies $/ \mathbf{5 6} /$.
} 
and events, preparing press releases, responding to and covering events on the ground (if the media are expected to be present), arranging media requests, supporting and organising journalistic conferences and events that could attract media attention and, thus, have a favourable effect on the image of the police in public $/ \mathbf{1 0} /, / 27 /, / 59 /, / 60 /$. They are also responsible for producing stories about the work of police officers of interest to the public, often also for preparing and conducting promotional and preventive campaigns (or participating in their planning with professional services) and communicating with citizens, covering substantially broad police areas of content, which covers crime, traffic, law and order, relations with trade unions, etc. Typical tasks include consulting with management, preparing communication strategies and campaigns, researching and evaluating public opinion /58/, and monitoring media reporting.

\section{Content and system limitations of police com- munication professionals}

While in foreign police organisations the profession of police communication expert is predominantly male $/ 55 /$, in the Slovenian police the situation is the opposite and in accordance with the image in the private sector, where a third is represented by women /18/, $/ 61 /, / 62 /$. Women have played an important role in public relations Cardwell and Rubin /63/ write, but only a few have occupied leadership positions. This is probably the difference with police organisations, in which the position of public relations representative is placed in a leading structure where women are usually underrepresented. Compared to private sector communication professionals who have an average of 10 years of work experience /18/, $/ 61 /, / 62 /{ }^{10}$, police communicators have the same level of education (diverse courses of study ${ }^{11}$ ), but are employed for a shorter period /55/, /59/.

With the increasing importance of public relations in the police, the proportion of police professionals in communication with communication education has increased over

\footnotetext{
${ }^{10}$ Almost half of the respondents $(41.1 \%)$ come from companies with more than 250 employees, and $17 \%$ from companies with up to 10 employees.
}

the years. Such employees are more easily and efficiently adapted to their responsibilities and environment, as they understand the needs and expectations of the public, according to Motschall and Cao /55/. On the contrary, since communicators with police powers have a better understanding of the organisation of the organisation and are familiar with police work, and, consequently, find it easier to interact with operational staff, it makes sense that both profiles are represented in the Communication Departments. In the vacancy notice Police Inspector in the Public Relations Sector, published in August 2018 /64/, the field of education was not defined (in general, Media education is not dominant among the employees in this field). The model of organisation of public relations of the Government of the Republic of Slovenia /65/ stipulates that, in this field, they are employed with a degree in Humanities, or in the field of Public Relations. Employment in foreign police organisations requires (or is at least desirable) a degree in the mother tongue, Journalism, Public Relations or Communications /66/; /67/, /68/, /69/. Nearly two-thirds of police public relations employees are presented by civilian communication professionals, and, in most, civilian experts also manage Communications Departments /70/. In the Public Relations Sector within the General Police Directorate in the Slovenian Police, the majority of employees represent so-called civilians. A civilian communications expert leads the service, and most civilians are also employed at the regional level. Surette and Richard /59/ consider that the decision to hire a civilian as a Communications Manager depends primarily on the characteristics of the police organisation leader and its organisational history, while Boyle /71/ estimates that the most optimal would be for the civilian Communications Department experts led by a "police officer". Civilian experts are recruited mainly because of their specific knowledge and experience $/ \mathbf{5 9} /, / \mathbf{7 0} /$, which are part of the normal workforce of private sector Communications Departments, and are increasingly required by police organisations.

\footnotetext{
${ }^{11}$ Compared to 1992 and 2002, the proportion of those with a Communications degree has quadrupled $/ \mathbf{5 5} /$.
} 
By recruiting civilians, we usually gain staff with previous (media or PR) experiences, gained outside the police, which is absolutely necessary in police ranks, as it would be difficult to find trained professionals within the organisation. Most often, employees include former journalists, as well as communications and marketing professionals, graphic and video designers, photographers and cameramen, social network managers or branding professionals. In a study by Surette and Richards /59/, approximately half of all police department employees had previous media experience. In the Slovenian police, most public relations employees have no previous media experience. This is due mainly to the filling of such posts, which usually involved internal redeployment, and, in the case of external recruitment, calls for career starters were sought. The above mentioned call $/ 64 /$ required seven months of work experience, but the area of work was not defined. Even in the case of the selection of regional PR representatives, media experience is not usually required, and their selection is primarily the responsibility of the police administration. Quite the opposite, foreign police organisations, in cases of external recruitment, require between two and five years of experience. Most often they involve working with the media, social media, communication skills (planning and evaluation; including media relations, social media and the press), and specific skills such as project management, marketing, branding, reputation management, risk management or crisis communication /67/, /68/, /69/, /72/, /73/, /74/, $/ 73 /, / 75 /$. Social network management is one of the most important and frequently required skills of communicators, as they are recognised by police organisations as key communication tools. Information in the digital communication system is spreading extremely fast, which is crucial for police action, which means that the police must be prepared for such communication. With the inclusion of social media, younger generations who no longer follow traditional media are involved in communication $/ 76 /$, and, at the same time, police are no longer so dependent on traditional media to communicate with a wider audience. Notably, larger police public relations organisations include marketing, analytical, and crisis communication professionals /77/, /69/. They often organise their work in terms of internal, media and digital communication, bringing content and organisation closer to departments in the private sector. With the transition to digital communication, the number of digital channels managed by communicators is growing steadily. The digital online revolution has created a new social and economic environment with new forms of profession /78/, and, above all, has accelerated communication, so that communicators must monitor the media constantly and be ready for immediate response /79/. Many police organisations, therefore, have dedicated departments for communicating with social networks, involving up to 10 employees, operating both nationally and in smaller police units, and by region. There are 5 permanent and 5 temporary staff in the Social Media Department of the Frankfurt Police Unit. Social media units are also set up in smaller units, such as the police in Iceland's Rekyavik $^{12}$, with three permanent and temporary staff. Between 1 and 7 social media experts are employed in each Dutch police communication unit ${ }^{13}$. Communication Departments use many different platforms, from websites, social networks, blogs, and communicate with various stakeholders /80/, which are scarcely controlled by institutions with limited resources. If organisations want to meet the criteria for modern public relations implementation, they must make drastic changes in the organisation and implementation of communication. With their hierarchical structure, police organisations find it more difficult to adapt to change, while, at the same time, treating public relations as an accompanying activity that merely follows the operational tasks of the police, rather than working with them. For this purpose, for example, the Dutch police reorganised the organisation of public relations completely, and

\footnotetext{
12 The unit employs a total of 291 police officers.

${ }^{13}$ They have more than 2,000 Twitter accounts, more than 300

Facebook profiles and 200 Instagram profiles.
} 
introduced so-called Newsroom model, that implements journalistic processes and Standards for the use of internal and external communication programmes. With the model, they coordinate and organise all media activities in one place (in therms of space and content) /81/. Although the basic requirements of the Public Relations profession have not changed, "new" skills and specialties are key /82/. With the rise of the web and new, especially digital forms of communication, the range of communicators' knowledge and skills is expanding, including in areas related to public relations, areas typically managed by advertisers and designers /79/ and Computer Science. Police communicators are also required to know how to use audio, video and photo processing software, web publishing applications, social media management tools, web site programming /66/, /74/, /83/, /84/). Some of the central responsibilities of police communicators even include preparing television scenarios /74/, marking and organising interview, and assisting marketing employees $/ 84 /$. Communicators, however, direct and manage communication, design, and establish continuous and interactive public relations $/ \mathbf{1 9} /$. We distinguish between two levels of public relations: Technical (or implementation board, covering activities such as preparing press releases, writing press releases and speeches, preparing and conducting press conferences, editing publications), and Managing level, which involves the use of media analysis and public opinion research, counselling, prevention or resolution of misunderstandings /85/. The managerial role includes strategic planning (planned, continuous and proactive action aimed at defining the strategy of the institution's operation and recognising the

\footnotetext{
${ }^{14}$ The duties of police public relations representatives in the Slovenian Police cover relations with the external public (resolving press questions and requests for interviews, audio and video statements, organising press conferences, informative meetings and press releases, photo events, preparing press releases and other police work contributions, preparing responses to incomplete, inaccurate or misleading media reporting, editing and posting on police websites, communicating on social networks, promotion and prevention activities, resolving issues of citizens and other interested public, protocol activity), communicating
}

strengths and weaknesses of the institution through analyses), implementation of communication activities (implementation of communication strategies through organisation and implementation of information and publicity events), consulting (in terms of the means, tools and communicational techniques, and the handling of specific cases), and research and analytical work (environmental research, trend identification and response recognition), writes Ašanin Gole /85/. It is important for communication professionals to act in both roles, but with an emphasis on the managerial role, which means that they must plan and manage their work at a strategic level /19/. A communication expert must think analytically, and be able to apply knowledge and strategies from one industry to another /79/. Slovenian public relations in the public sector are lagging behind in the development of high professional

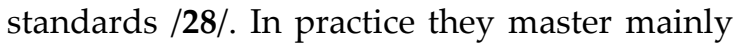
technical knowledge, and there is very little management knowledge /85/, /86/. This is especially pronounced in police public relations. Mawby /70/ notes that police communication professionals are increasingly assuming organisational and supportive functions /70/. The responsibilities of police representatives for public relations in the Slovenian Police /56/ also do not deviate in this respect, since they focus primarily on the implementation side ${ }^{14}$, and the strategic role is emphasised only in the context of consulting, organisation and coordination in public relations. The main tasks of police communication experts are focused mainly on media relations, ie communication with the media and dealing with their demands. In this role, the communicator primarily identifies information that is relevant and relevant to the public, disseminates it, adjusts the content by

with the internal public (editing and publishing on the intranet, resolving issues of police officers and their initiatives and proposals, editing a magazine, organising or participating in the organisation of receptions for successful police officers, various anniversary celebrations, visits by the Ministry of the Interior and the police in police units, meetings and meetings with employees, participation in the organisation of police games and other sports events for employees, preparation of speeches, press releases, reminders, thanks, counseling and preparation of employees for public appearances, organisation of professional consultations, training and education) 
communication channel and the public, manages social networks and coordinates events. Police communicators most often provide information about criminal events in their work /30/. This undoubtedly benefits them in communicating with the public, since, by supplying information constantly, they have easier access to the media, closer relations with journalists, and more opportunities for media coverage of content. In some foreign police organisations, however, management is a much more important role. They emphasise the implementation of communication activities, such as the implementation of communication strategies and campaigns, and the promotion and maintenance of a positive reputation /66/, /68/, /74/ and strategic planning, such as the planning and preparation of communication strategies /66/, /67/, /68/, /69/, /74/, /87/. They also emphasise the advisory role, ie advising strategic management and project managers on communication aspects, intentions and project plans, on internal and external communication issues /69/, and research and analytical work, such as analysing and identifying opportunities and threats that would affect the reputation, understanding and analysis of statistics, and participation in development /67/, /68/, /69/, /87/. Despite the increased workload and the low number of employees ${ }^{15}$, Slovenian communication experts in the private sector, lack human resources, but a much bigger problem is lack of knowledge, which is not exposed by foreign police communication experts $/ 2 /, / 60 /$, /55/. According to Edes /58/, communication professionals in Central and Eastern Europe are characterised by having only basic training, and the problem is more pronounced where there is no professional association of communicators in the public sector ${ }^{16}$. In an ever-changing and evolving field of Public Relations, involving a variety of communication strategies, combined with advanced, innovative and, above all, two-way digital channels, regular training is crucial. Police organisations therefore need constant

\footnotetext{
${ }^{15}$ The lack of Human Resources is not one of the main constraints on work for Slovenian communication professionals in the private sector, although most companies employ only one to two communication professionals (64\%), and most find that the volume of work has increased over the past three years /95/.
}

additional training. Following the occupation of the post of Communication Expert, the Slovenian Police do not have a training programme for this job, even though the importance of training employees in this field has already been recognised (Police, $/ \mathbf{8 8} /{ }^{17}$ ). The training of Slovenian police communicators would be of particular benefit, since the organisation of public relations in the Slovenian Police has remained the same over the last decades, but, mostly, the same employees. That they remain in their jobs is understandable, and also expected because they are occupied by individuals with no operational experience to help them occupy another police position. At the same time, training is crucial when communication professionals do not have prior experience, an appropriate level or direction of education, and skills learned, thus gaining more insight into the journalistic profession. At the same time, they can learn how to take control of media communication and maximise their effectiveness in communicating with journalists /89/. Training aimed at understanding journalistic work helps communicators to understand better journalists' strategies in preparing news, and to know media formats, patterns and deadlines, and to establish more positive relationships with journalists /90/. Adequate education is encouraged in foreign police organisations, especially in the fields of Media Communication, Public Relations and Reputation Management /10/. Foreign police communication professionals often receive onthe-job training $/ 55 /, / 59 /$, usually on entry into the field $/ 59 /$, and at least 50 hours of training /2/, and up to 40 hours per year /10/. Police communicators are most often educated on how to handle crisis situations and make statements, how to cover routine and extraordinary events, conduct interviews, prepare a press conference, how to act in cases of information leakage, inappropriate actions by police officers and similar events $/ \mathbf{1 0} /$. As

\footnotetext{
${ }^{16}$ In Slovenia, the professional association is well catered for by the Slovenian Public Relations Society, which also operates a section for communicators in the public sector. ${ }_{17}$ As stated, incompetence can prove to be a key drawback and investment in education is needed.
} 
Surette $/ 60 /$ notes, more and more time ${ }^{18}$ is devoted to training among police communicators, while Motscall and Cao /55/ advocate a holistic and interdisciplinary approach that involves informing and publicising strategies. The training of police communicators in the Dutch police depends on the work strategy - most of the training is carried out by internal experts, and a basic training programme is prepared for career starters. In the case of employment in St. Charles County Police /83/ a candidate is referred to Media Incident and Accident Management Training. Again, other police organisations consider professional development a preference for the recruitment of police communicators, or require further training in formal education as a condition of employment $/ 66 /$. The lack of human resources is particularly acute due to the reliance of journalists on police information, media demands that require an instant response, the proliferation of police communicators' activities, the required skills and tools used, and, in general, the increasing importance of police public relations. Public relations are among those activities that should not be run out of funds because they are not available /91/. However, it is precisely the lack of resources and staff that are generally the biggest obstacles for police communication professionals $/ 2 /, / 55 /$, /91/. The number of police communicators employed varies depending on the various police organisations, but the standard of one communicator per hundred, up to two hundred, has developed in police organisations. Police organisations are increasingly allocating resources to the field of Communication, and employing additional communication professionals ${ }^{19} / \mathbf{1 5} /$. Motschall and Liqun Cao /55/ found that, on average, police organisations employ 1.5 police communication experts per fewer than 100 employees, 1.3 (100 to 199), 1.5 (200 to 499), 1.9 (500 to 999$)$ and $3.1(1,000)$ or more). While one communications specialist is typically recruited by US police units $\mathbf{2} /$, there is not a single one with only one employee in England, Wales and

\footnotetext{
${ }^{18}$ In Surette's /60/ study, the time devoted to education by foreign police communicators more than doubled between 1993 and 1998.
}

Scotland /93/. One communicator per 100 employees is employed in some German units. There is one communications specialist in the Dutch police force per 200 police officers, in addition to temporary traineeships. Kešetović /53/ believes that one employee can perform this work in a unit with 100 employees. Serajnik and Vidrih /19/ similarly add that one employee in a Ministry or government department or office is significantly understaffed. Although 20 Ministries and government departments employed one communicator 20 years ago, such organisations are a rarity nowadays. In the Slovenian police, at the regional level, with the exception of the Ljubljana Police Directorate, where two persons are employed in this field, only one public relations representative is employed, and the number of employees and the organisation itself has remained the same over the last decades, regardless of needs and trends. The number of regional public relations representatives in Slovenia is undoubtedly undernourished, and additional communications professionals should be employed in Maribor (with 1,000 employees), Koper (900) and Novo mesto (925). Additional staffing power would be useful to communications professionals, especially in cases of crisis situations, or more significant events, when a haphazard response is necessary due to the nature of the crisis event. In such situations, we often run out of time to communicate and cover the various communication channels fully, as well as other, nonetheless important tasks that police communicators should perform on a regular basis, such as communication planning, preparation and implementation of prevention and promotion projects and campaigns, supplementation communication with video and photo content, preparation of interesting contributions...

Public relations management is one of the managerial functions, and communicators can only work with decision-making structures 191/. The professional performance of a communication expert therefore depends on

\footnotetext{
${ }^{19}$ In the English, Welsh and Scottish units, the number of communication professionals almost doubled between 2001 and 2010.
} 
working in a position that is in close contact with the management he trusts, and his confidence depends largely on him, his charisma, connection and building credibility with his superiors, and in the relationship with media representatives or other public /94/. Acting in close proximity to the top police leadership enables the communicator to respond directly to all events, and to be involved in the decision-making and work of top management /53/. Such a placement gives him a holistic view of what is happening and access to the latest and most important information. The vast majority of Slovenian communicators are not part of the Management Board /95/, but have direct access to management. Most are involved to some extent in strategic planning and decision-making and report directly to management /96/. Like the Slovenians, foreign police communicators are placed in the leadership of the police unit organisationally $/ \mathbf{1 0} /$. They meet with their management frequently, most every day, or several times a day, to ensure that the department's public image is consistent with the leader's philosophy $/ 2 /$. The placement of police communication experts in the Slovenian Police, both at the regional and national levels, enables communicators to gain access to leadership on a daily basis, as well as attendance at Director Colleges, as well as involvement in strategic planning, decisionmaking and access to information. With accountability directly to the top management of the organisation, direct and day-to-day access, police communicators also have ample opportunity to influence management through proposals to improve their position within the organisation. Nonetheless, the satisfaction of police communication professionals varies with their professional status. Surette $/ \mathbf{6 0}$ / notes that civilian experts are less satisfied than their counterparts with police powers. The latter have more work experience within the police organisation and receive a higher salary, while civilian roles are generally expected to be occupied by lower-paid women with "Media" education and experience outside the police. Those with police authority are expected to benefit more, have easier access to their leaders, and cover "important," high-profile stories, while civilian experts should be charged with more marginal, routine, day-to-day duties. Similarly, Zerfass /97/ notes that, in the study of foreign civilian communication professionals, the main indicators of satisfaction with the work of a communication specialist include, above all, interesting and varied tasks, good career prospects and clients, and superiors who value the work of communicators; the most satisfied are those with longer work experience /97/. Based on the above indicators /60/, /97/, we can conclude that Slovenian police communicators operate in an environment that enables them to be satisfied with their work, as they have police powers, are placed in, or have management authority over, easy access, and they have been in work for a long time, even though job satisfaction is undoubtedly a matter for the individual and a mix of different factors.

\section{Conclusion}

Formerly ancillary and supportive functions, police public relations today are an integral part of the police organisation, which is key to managing the institution's reputation effectively, building people's confidence and building their relationship with the police. Despite the growing popularity of digital communication channels that are independent of traditional media, both journalists and police communicators are still highly dependent on each other. On the one hand, when police communication experts spend most of their time communicating criminal information to journalists, the media, on the other hand, devote enormous amount of media space and rely on the information of police organisations to fill it. The consequence is a distorted media account of criminality, both qualitatively and quantitatively. A step closer to a more objective media image is not only quality journalism, but also quality public relations, which, however, face systemic and content constraints. As in the broader public sector, police public relations representatives, in comparison to their colleagues in the private sector, are struggling with a lack of media experience and adequate education and knowledge of modern skills. There are several key reasons for this situation: Inadequate staffing policy, inadequate 
organisation and implementation of public relations, and a lack of staff and staff training. The transformation of communication through technological and social innovation has changed the role of (even public) organisations /23/. The public otherwise collects, receives and disseminates information. Organisations are no longer just mediators of information for journalists, but they create and distribute content through their own platforms /98/. At the same time, public relations is extremely involved in technological development, and digital communication is increasingly at the forefront. With the expansion of the range of skills and the required knowledge of areas that traditionally fall outside the scope of public relations, it is becoming increasingly clear that the amount of knowledge and experience required equals, whether it is public relations in a private agency or in a public sector. In such an environment, training of communicators, their experience, following modern guidelines and continuous training are key. Execution of public relations can be very different when practiced by people with different education and experience (86 In police public relations, communicators from the civilian ranks are still treated differently than their colleagues who have built their careers within the police force. However, although a good knowledge of police work is of the utmost importance, it is usually not sufficient for a quality and modern public relations exercise. Indeed, today's communication professionals need to be more educated, more specific, technically savvy, flexible and open to change /79/, while being extremely adept at digital communication. Particularly in foreign police organisations, the proportion of civilian professionals with a communication background has increased significantly over the years, as they usually master the skills that are more difficult to find among police officers. Although police organisations, with their hierarchical structure, find it more difficult to adapt to change, foreign, even smaller police institutions are aware of the requirements of the new media landscape, following it by adapting and reorganising their work (for example, by introducing a corporate editorial model, integrating analysts into the field), public relations, hiring external crisis communication experts and agencies to carry out major campaigns, opening social media departments, additional hiring of digital media professionals) and taking care of the continuing education of employees (through regular crisis communication training, diversification training, modern skills and tools). There are fewer and fewer police organisations that have not adapted (or even subordinated) digital communications to public relations organisations and implementations. However, regardless of trends, actual staffing needs of specific personnel and the practice of foreign police institutions, the organisation of public relations in the Slovenian police has remained the same over the last decades, with mostly the same employees. Therefore, careful consideration is needed to its new design and implementation, as well as staff acquisition. Compared to foreign studies $/ \mathbf{1 1} /, / 55 /, / 93 /$, the number of regional public relations representatives in the Slovenian Police is significantly under-resourced, and additional staff should be recruited from larger police departments. Given the lack of fluctuation between them and the broader range of skills required, a change in personnel policy is also necessary in terms of prioritising the recruitment of staff with appropriate (including specific) knowledge and education (and a clear definition of requirements already in the Tender conditions). Since basic training is not regulated within the police, and other training within the police is carried out rarely, communicators should be allowed to attend professional conferences and training outside the police. The above limitations are undoubtedly some of the key reasons that communicators devote most of their time to the technical level of public relations, even if they need to act more strategically in a more qualitative and modern way of performing public relations. Regardless of whether it is a public administration or a private company, modern public relations is a place only for educated individuals who are able to keep up with the latest trends and technological developments. Only in this way will we move closer to quality public relations, which is an indicator of quality and an ethical imperative of modern organisations /91/. 
Notes

/1/ Pečar, J. (2001). Policija v (lokalni) skupnosti. Dnevi varstvoslovja. Ljubljana. Visoka policijskovarnostna šola.

/2/ Chermak, S. in Weiss, A. (2006). Community Policing in the news media, Police Quarterly, 9(2), 135- 160

/3/ Chermak, S. (1994). Body Count News: How Crime Is Presented in the News Media, Justice Quarterly. 11(4). 561-582

/4/ Meško, G. (2001). V skupnost usmerjeno policijsko delo - izziv za Slovensko policijo? Teorija in praksa. 38(2), 272-289

/5/ Zhao, J. S. in Cao, L. (2005). Confidence in the police in Latin America. Journal of Criminal Justice, 33, 403-412

/6/ Ekins, E. (2016). Policing in America: Understanding Public Attitudes Toward the Police, Cato Institute.

/7/ Ritchie, S. (2015). Community Engagement, Democracy and Public Policy: A Practitioner Perspective. V Wankhade, P. in Weir, D (ur.), Police Services. Leadership and Management Perspectives. Springer.

/8/ Adlam, R. (2002). Governmental Rationalities in Police Leadership: An Essay Exploring some of the 'Deep Structure' in Police Leadership Praxis. Policing and Society, 12/1, 15-36

19/ Mawby, R. C. (2002b). Policing Images. Policing, communication and legitimacy. Cullompton: Willan Publishing

/10/ Lovell, J. S. (2002). Media Power \& Information Control: A Study of Police Organizations \& Media Relations. US Department of Justice. Pridobljeno na:

https://www.ncjrs.gov/pdffiles1/nij/grants/19706 $0 . p d f$

/11/ Kešetović, Ž., Bajagić, M. in Koraljić, N. (2006). Police-Media Relatins in the Transition: From Aurocratic Regime to Democracy. Varstvoslovje, $8(3,4), 213-222$

/12/ Surette, R. (1998). Media, Crime and Criminal Justice. New York: Wadsworth Publishing

/13/ Brown, B. in Benedict, R. (2002). Perceptions of the Police. Past Findings, Methodological Issues, Conceptual Issues and Policy Implications. Policing, 25(3), 543-580.

/14/ Dowler, K. (2003). Media Consumption and Public Attitudes Toward crime and justice: the relationship between fear of crime, punitive attitudes, and perceived police effectiveness. Journal of Criminal Justice and Popular Culture, 10(2), 109-126

/15/ Edwards, B. (2007). Media: Effects on Attitudes toward Police and Fear of Criminal Victimization. Electronic Theses and Dissertations. Paper
2048. Pridobljeno

na: http://dc.etsu.edu/etd/2048

/16/ Cooke, L. in Sturges, P. 2009. Police and media relations in an era of Freedom of Information. Policing and Society. 19(4) 406-424

/17/ Bučar - Ručman, A. (2009). Late Modernity, Risk and the Construction of Fear of Crime. V Crime, Media and Fear of Crime. (Meško, G., Cockcroft, T. Crawford, A. in Lemaitre, A. ur). Faculty of Criminal Justice and Security, University of Maribor, Ljubljana

/18/ Zerfass, A., Verčič, D., Verhoeven, P., Moreno, A. in Tench, R. (2019). European Communication Monitor. Exploring Trust in the profession, transparency, artificial intelligence and new content strategies. EUPRERA/EACD, Bruselj

/19/ Serajnik, S. N., in Vidrih, B. (2001). Vladni odnosi z javnostmi: model organiziranosti vladnih odnosov z javnostmi v Sloveniji. Teorija in praksa, 38(4), 650-674

/20/ Baker, B. (2012) Government Public Information. Portal to the Public. V The Handbook of Strategic Public Relations and integrated Marketing Communication. (Caywood, C.L., ur) McGrawHill Education

/21/ Bučar, R. A. in Meško, G. 2006. Presentation of Police Activities in the Mass Media. Varstvoslovje 8(3-4). 223-234.

/22/ Greer, C. and Reiner, R. (2015). Mediated Mayhem: Media, Crime and Criminal Justice. Oxford Handbook of Criminology, Oxford University Press, UK

/23/ Stephens, D. W., Hill, J. in Greenberg, S. (2011). Strategic Communication Practices. A Toolkit for Police Executives. U.S. Department of Justice.

/24/ Reiner, R. (2003). Policing and the Media. V Handbook of Policing. (Newburn, T., ur.) Willan Publishing, London.

/25/ Kešetović, Ž. (2007). Improving Police and Media Relations in Serbia. Sociologija. Mintis ir veiksmas. 2(20),92-108

/26/ Gorenak, I. in Pagon, M. (2006). Vpliv organizacijskega komuniciranja na zadovoljstvo policistov pri delu. Organizacija, 39/4, 247-253

/27/ Guffey, J. E. (1992). The Police and the Media: Proposals for Managing Conflict Productively, American Journal of Police, 11(1), 33-51

/28/ Chermak, S. (1995). Image Control: How Police Affect the Presentation of Crime News, American Journal of Police, 14(2), 21-43

/29/ Chermak, S. (1997). The Presentation of Drugs in the News Media: The News Sources Involved in the Construction of Social Problems, Justice Quarterly, 14(4), 687-718

/30/ Chermak, S. in Weiss, A. (2005). Maintaining legitimacy using external communication 
strategies: An analysis of police-media relations. Journal of Criminal Justice. 33 (2005) 501- 512

/31/ Dailey, R. in Wenger, D. H. (2016). Source Variety, Event Frequency and Context in Newspaper Crime Reporting. International Journal of Communication, 10(2016), 1700-1720

/32/ McGovern, A. in Lee, M. (2010). Cop[ying] it Sweet: Police Media Units and the Making of News, The Australian and New Zealand Journal of Criminology. 43(3), 444-464

/33/ Ashcroft, J., Daniels, D.J. in Hart, S. V. (2003). Factors That Influence Public Opinion of the Police. U.S. Department of Justice. Office of Justice Programs. National Institute of Justice.

/34/ Reiner, R. (2007). Policing and the Media. V Handbook of Policing. (Newburn, T., ur.) Willan Publishing, London.

135/ Chadee, D. in Ditton, J. (2005). Fear of crime and the media: Assessing the lack of relationship. 1(3), 322-332

136/ Reuband, K. H. (2009). Portrayals of Crime in the German Mass Media. Trends, Patterns and Impact on Fear of Crime. V Crime, Media and Fear of Crime. (Meško, G., Cockcroft, T. Crawford, A. in Lemaitre, A. ur). Faculty of Criminal Justice and Security, University of Maribor, Ljubljana

/37/ Meško, G. in Areh, I. (2003). Strah pred kriminaliteto $\mathrm{v}$ urbanih okoljih. Revija $z a$ kriminalistiko in kriminologijo. 54/3, 144-152

138/ Cockcroft, T. (2009). Late Modernity, Risk and the Construction of Fear of Crime. V Crime, Media and Fear of Crime. (Meško, G., Cockcroft, T. Crawford, A. in Lemaitre, A. ur). Faculty of Criminal Justice and Security, University of Maribor, Ljubljana

/39/ Beck, U. (2001). Družba tveganja. Na poti v neko drugo moderno. Ljubljana.

/40/ Brechner Center Issue Brief (2018). Transparency and Media Relations in High-profile Police cases. University of Florida. Pridobljeno na: http://brechner.org/wpcontent/uploads/2018/06/2018-06-07-UFBrechner-report-and-recommendations-reKCSO-Public-Information-Practices.pdf

/41/ Prezelj, I. (2001). Grožnje varnosti, varnostna tveganja in izzivi v sodobni družbi. Teorija in praksa. 38(1) 127-141

/42/ Simon, J. (2007). Governing Through Crime. Oxford. Oxford University Press.

/43/ Lasthuizen, K., Eeuwijk, B. A. P., in Huberts, L. W. J. C. (2005). How Policing Can Reduce Feelings of Insecurity: Results from Survey Research in the Netherlands. Police Practice and Research, 6(4), 375-390.

/44/ Gačnik, M. Merslavič, M. in Zavrl, F. (1999). Odnosi z mediji med ideologijo, normativo in pragmatizmom. Teorija in praksa, 36(4), 609-617
/45/ Bučar, R. A. (2011). Medijsko poročanje o kriminaliteti v Sloveniji. Revija za kriminalistiko in kriminologijo, 62(1), 23-38

/46/ Reiner, R. (1992). The politics of the Police, University of Toronto

/47/ Petrovec, D. (2009). Violence in the Media (Selected Cases in Slovene Media). V Crime, Media and Fear of Crime. (Meško, G., Cockcroft, T. Crawford, A. in Lemaitre, A. ur). Faculty of Criminal Justice and Security, University of Maribor, Ljubljana

/48/ Luthar, B., Jontes, D., Šadl, Z. (2006). Medijske reprezentacije družinskega nasilja. Center za raziskovanje družbenega komuniciranja. Fakulteta za družbene vede.

/49/ Prpič, M. (2006). Poročanje o dnevnih dogodkih v osrednjih večernih poročilih. Komercialna in javna televizija. V Petkovič, B. (ur)., Mediji za državljane, str. 78-116. Ljubljana: Mediawatch.

150/ Petrovec, D. (2003). Violence in the media. The Extent and the Influence of Violence in the Media in Slovenia. Ljubljana: Mirovni inštitut.

151/ Ferfila, B. in Kos, M. (2002). Politično komuniciranje. FDV, Ljubljana

/52/ Broom, G. M., Cutlip, S. M. (2009) Cutlip \& Center's Effective Public Relations. Tenth Edition. 2009. Pearson Education International.

/53/ Kešetović, Ž. (2000). Odnosi policije sa javnošću. Viša škola unutrašnjih poslova, Beograd.

/54/ Serajnik, S. N. (2013). Kompleksnost obrambnovojaškega okolja narekuje strateško upravljanje odnosov z javnostmi. Sodobni vojaški izzivi. 15(2), 11-31

/55/ Motschall, M. in Cao, L. (2002). An Analysis of the public relations role of the police public information officer, Police Quarterly. 5(2), 152-180

/56/ Policija. (2017). Usmeritve za delo policije na področju odnosov z javnostmi.

/57/ Policija. (2013). Zakon o organiziranosti in delu v policiji.

/58/ Edes, B. W. (2000). The Role of Government Information Officers. Journal of Government Information, 27(4), 455-469

/59/ Surette, R., \& Richard, A. (1995). Public information officers: A descriptive study of crime news gatekeeper. Journal of Criminal Justice, 23, 325- 336.

/60/ Surette, R. (2001). Public information officers: The civilianization of a criminal justice profession. Journal of Criminal Justice, 29(2), 107117

/61/ Chartered Institute of Public Relations (CIPR). (2017). State of the proffesion. Pridobljeno na https://www.cipr.co.uk/sites/default/files/10911_ State\%20of\%20PR\%202017_f1.pdf

/62/ Marketing magazin. (2017a). Kako cenjeni so komunikatorji v Sloveniji? Dostopno na: 
http://www.marketingmagazin.si/novice/pr/138 58/kako-cenjeni-so-komunikatorji-v-sloveniji

/63/ Cardwell, J. in Rubin, D. Corporate Governance. Operating as an Open Book. V The Handbook Of Strategic Public Relations and Integrated Marketing Communications.

/64/ Policija, (2019). Javni natečaj za zasedbo uradniškega delovnega mesta na Generalni policijski upravi, Sektorju za odnose z javnostmi.

/65/ Vlada Republike Slovenije. (2007). Model organiziranosti odnosov z javnostmi na ravni Vlade Republike Slovenije.

/66/ North Yorkshire Police. (2016). Communications officer Candidate pack.

/67/ Metropolitan Police Service (2017). Police Staff Information Pack, Media and Communication Manager.

/68/ Watsonville Police Department. (2018). Police media and community specialist. Employment Opportunity. Pridobljeno na: www.cityofwatsonville.com

/69/ Politie. (2019). Communicatieadviseurwoordvoerder. Pridobljeno na: https://kombijde.mesapolitie.nl/vacatures/Vakge bied/Communicatie

/70/ Mawby, R. C. (2002a). Continuity and change, convergence and divergence: The policy and practise of police media relations. Criminology $\mathcal{E}$ Criminal justice, 2(3), 303-324

/71/ Boyle, R. (1999). Spotlighting the Police: Changing U.K. Police-Media Relations in the 1990s. International Journal of the Sociology of Law, 27, 229-250

/72/ Newport News Police Department, (2015). Police information Officer.

/73/ North Yorkshire Police. (2019). Corporate Communications Officer. Dostopno preko: https://www.linkedin.com/jobs/view/corporatecommunications-officer-temporary-at-northyorkshire-police1187023057/?originalSubdomain=uk

/74/ Mesa police, (2018). Police Media Relations Specialist. Dostopno preko: http://apps.mesaaz.gov/JobDescriptions/Docum ents/JobDescriptions/cs4888.pdf

175/ West Midlands Police, Birmingham. (2019). Communication Officer. Pridobljeno na: https://www.linkedin.com/jobs/view/communic ations-officer-at-west-midlands-police1290993531?originalSubdomain $=\mathrm{uk}$

/76/ Edelman, R. Corporate Governance. Operating as an Open Book. V The Handbook Of Strategic Public Relations and Integrated Marketing Communications. Caywood, C.L. (ur). 2012

/77/Moss, C. (2016). Der Newsroom in der Unternehmens-kommunikation. Springer.
/78/ Plenković, M. (2018). Spokersperson - New profession in Public communication. Informatologia, 51(3-4), 221-242

179/ McDougal, T. in Stocker, K. Corporate Governance. Operating as an Open Book. V The Handbook Of Strategic Public Relations and Integrated Marketing Communications. Caywood, C.L. (ur). 2012

/80/Zerfass, A. in Schramm, D. M. (2014). Social media newsrooms in public relations: a conseptual framework and corporate practices in three countries. Public Relations Review, 40(1)

/81/ Keel, G. in Niederhäuser, M. (2016). Corporate Newsrooms in der Schweiz.

/82/ Cardwell and Rubin v Caywood, C.L. (ur) 2012. The Handbook of Strategic Public Relations and Integrated Marketing Communications.

183/ St. Charles County Police Department. (2015). Public Affairs Officer. Pridobljeno na: www.sccmo.org

184/ NSW Police Force, 2019. Media officer - Media Unit. Pridobljeno na: http://files.jobs.nsw.gov.au

/85/ Ašanin G., P. (1999). Strateško načrtovanje odnosov z javnostmi. Teorija in praksa, 36/4, 544557

/86/ Grunig, J.E. in Jaatinen, M. (1999). Strategic, Symmetrical Public Relations in Government: From Pluralism to Societal Corporatism. Journal of Communication Management, 3(3), 218-234

/87/ Birningham. (2019). Communications Officer. Pridobljeno na: https://www.linkedin.com/jobs/view/1290993531 /?trk=d_flagship3_salary_explorer\&refId=9c15c9 1e-6c5b-4929-ac92-596450215639

/88/ Policija. (2002). Usmeritve za komuniciranje Policije $z$ javnostmi $v$ kriznih in konfliktnih okoliščinah.

/89/ Rosenthal v Lovell, J. S. (2002). Media Power \& Information Control: A Study of Police Organizations $\mathcal{E}$ Media Relations. US Department of Justice. Pridobljeno

na: https://www.ncjrs.gov/pdffiles1/nij/grants/19706 $0 . p d f$

190/ Jones v Lovell, J. S. (2002). Media Power \& Information Control: A Study of Police Organizations $\mathcal{E}$ Media Relations. US Department of Justice. Pridobljeno

na: https://www.ncjrs.gov/pdffiles1/nij/grants/19706 $0 . p d f$

/91/ Verčič, D., Zavrl, F. in Rijavec, P. (2002). Odnosi z mediji. GV Založba, Ljubljana

192/ Mawby, R. C. (2001). Promoting the Police? The rise of Police Image Work. Criminal Justice Matters, 42(1) 44-43

193/ Mawby, R. C. (2007). Police Service Corporate Communications: A Survey of forces in England, Wales and Scotland. Centre for Criminal Justice 
Policy and Research. Pridobljeno na: https://sp.ukdataservice.ac.uk/doc/6927/mrdoc/p df/6927report.pdf

194/ Kokot R. G. (2007). Najpomembnejše je zaupanje. Pridobljeno na: http://www.piar.si/ /novice/najpomembnejse-je-zaupanje/

195/ Marketing Magazin. (2017c). Koliko so vredni slovenski komunikatorji.

196/ Marketing magazin, (2017b). Največja težava piarovcev: pomanjkanje človeških in finančnih virov. Pridobljeno

na: http://www.marketingmagazin.si/novice/pr/14 326/najvecja-tezava-piarovcev-pomanjkanjecloveskih-in-financnih-virov

/97/ Zerfass, A., Tench, R., Verhoeven, P., Verčič, D. in Moreno, A. (2018). European Communication Monitor 2018. European Association of Communication Directors in European Public Relations Education and Research Association: Berlin

198/ Verčič, D. in Tkalac Verčič, A. (2016). The new publicity: From reflexive to reflective mediatisation. Public relations review. 42(4) 493-498 . 